\title{
EVOLUTION OF GENDER-NEUTRAL PRONOUNS FROM W. SHAKESPEARE TO MODERN MEDIA
}

\section{Klymenko O. L.}

\section{INTRODUCTION}

Language is one of the most important ways to identify one's gender, as gender is shown by the choice of linguistic constructions. Any change in the perception of gender is reflected in the language. Therefore it is clear that perception of gender has led to specific changes in the language and this gives the basis for linguistic research ${ }^{1}$.

As a cultural phenomenon gender evokes a huge interest among scientists ${ }^{2}$. Nevertheless there is a scientific gap in studying the influence of gender on the way people speak from historical perspective. Therefore the relevance of this research has been determined by the interest to studying the connection between gender identity and language of literature and mass media. The research focuses on studying the concept of gender in the linguistics, as well as reveals the burning necessity of being gender politically correct.

For the first time the notion "gender" was used by Robert Stoller, an American psychologist, who defined gender as fixed roles of social behavior of men and women. In order to clarify biological and social differences of men and women's behavior he tried to divide the sexuality into two aspects: biological, related to "sex", and social, related to "gender" . Recognition of the analytical independence of these concepts is essential for understanding the interactional work involved in being a gendered person in society ${ }^{4}$.

1 Ehrlich S. Language and Gender. The Handbook of Applied Linguistics. Blackwell Publishing Ltd, 2004. P. 304.

${ }^{2}$ Maltz D., Borker R. A Cultural Approach to Male-Female Miscommunication. Language and Social Identity. Cambridge : Cambridge University Press, 1982. P. 196-216.

3 Stoller R.J. Sex and Gender: On the Development of Masculinity and Femininity. New York : Science House, 1968. P. 226.

${ }^{4}$ West C., Zimmerman D. Doing Gender. Gender and Discourse. London : Sage, 1987. P. 1. 
It is generally known that "Gender Studies" have originated from so called "Women's Studies"5. So at one point gender studies came from feminism. The appearance of the notion of gender identity gives the gender studies a new direction. The feminism and the expansion of the perception of gender have led to specific linguistic changes and understanding the necessity of gender political correctness in language ${ }^{6}$. The representatives from feministic and LGBTQ + communities claim that the usage of gender-marked words imposes stereotypical perception of the world and in order to avoid gender asymmetry (not proportional presentation of different genders) gender neutral pronouns are to be used ${ }^{7}$.

The English language has been known to lack a singular pronoun that would not be gender-specific, and could be used to correspond with such pronouns as everyone or someone. Historical development has led to the take-up of initially plural pronoun they for this purpose more than half a millennium ago. That may sound odd for someone following the recent development of the English language, but anyone using they or them pronouns in their modern controversial discourse is tapping into a long history of their usage as a singular pronoun in the English language for centuries, both by the common folk and by such grandees of the English literature as William Shakespeare.

Despite such an honorable background, the pronoun has seen a considerable push-back, with opponents of its usage pointing out that it's grammatically incorrect. Conservative commentators have also been quick to dismiss its use as an act of mere political correctness. For example, a notable University of Toronto professor Jordan Peterson, proclaimed in 2016: "I don't recognize another person's right to determine what pronouns I use to address them". ${ }^{\circ}$

However, the debate that has been raging in the mid-2010s seems to have been more or less settled in the late 2019. Firstly, Merriam-Webster

5 Brown M., Moorer R. Applied Research on Gender and Women's Studies. International Encyclopedia of the Social \& Behavioral Sciences (Second Edition). 2015. URL: https://www.sciencedirect.com/topics/social-sciences/womens-studies.

${ }^{6}$ Butler J. Gender Trouble: Feminism and the Subversion of Identity. New York : Routledge, 1990.

${ }^{7}$ Frank F., Anshen F. Language and the Sexes. State University of New York Press, 1991.

${ }^{8}$ North A. The Past, Present and Future of the Singular "They". The pronoun is Merriam-Webster's Word of the Year. Here's why. Vox. 2019. Dec 13. 2019. URL: https://www.vox.com/2019/12/13/21011537/they-merriam-webster-pronounsnonbinary-word-year. 
added the singular pronoun they, used to refer to "a single person whose gender identity is non-binary", or to "a person whose gender is unknown or is intentionally not revealed", to their vocabulary in September of 2019, going one step further later in the year to proclaim the pronoun as its Word of the Year 2019. Around the same time, in October 2019, it was endorsed by the American Psychological Association (APA) to be used in scholarly writing ${ }^{9}$.

As for the data analyzed for this research, we noticed that numerous writers traditionally used pronouns he/him/his as gender neutral ones, despite the fact that they can be interpreted as gender-specific ones as well ${ }^{10}$. However, the examples of using they, them, themselves and their with such words as one (every one, no one), a person, an individual, each can be found in literary works of many well-known authors. Thus, the usage of singular they as gender-neutral pronoun is considered an alternative to masculine pronoun $h e$.

\section{W. Shakespeare paved the way to gender neutral pronouns in the English literature}

William Shakespeare's literary works provide linguistic opportunities for numerous academic studies of his language: Shakespeare's style and his lexical innovations ${ }^{11}$, Shakespearian word-formation ${ }^{12}$, Shakespeare's use of colloquial language ${ }^{13}$, the language of Shakespeare's plays ${ }^{14}$. "Just

${ }^{9}$ North A. The Past, Present and Future of the Singular "They". The pronoun is Merriam-Webster's Word of the Year. Here's why. Vox. 2019. Dec 13. URL: https://www.vox.com/2019/12/13/21011537/they-merriam-webster-pronounsnonbinary-word-year.

${ }^{10}$ The American Heritage. Book of English Usage. A Practical and Authoritative Guide to Contemporary English. Boston : Houghton Mifflin, 1996. URL: http://web.archive.org/web/20080415023135/http://www.bartleby.com:80/64/ C005/012.html\#HE.

11 Gordon G. Shakespeare's English. Shakespearian Comedy. Oxford, reprint, 1945. P. 142.

${ }^{12}$ Salmon V. Some Functions of Shakespearian Word-formation. Shakespeare Survey 23: Shakespeare's Language. Cambridge University Press. 1970. P. 13-26; Smithers G.V. Guide-Lines for Interpreting the Uses of the Suffix -ed in Shakespeare's English. Shakespeare Survey 23: Shakespeare's Language. Cambridge University Press, 1970. P. 27-37.

${ }^{13}$ Hudson K. Shakespeare's Use of Colloquial Language. Shakespeare Survey 23: Shakespeare's Language. Cambridge University Press. 1970. P. 39-48.

14 Evans B.I. The Language of Shakespeare's Plays. London, 3rd ed. 1964. P. 143. 
as Shakespeare was able to catch English morphology and syntax as they changed" $"$, he can also truly be called a pioneer in the introduction of the pronoun they as a gender neutral one.

For example, in the tragedy of "Romeo and Juliet"16 in the dialogue, held between two males Friar Laurence and Friar John, singular they is used because there is no information on a person who is the subject of the discussion:

FRIAR LAURENCE. Who bare my letter, then, to Romeo?

FRIAR JOHN. I could not send it, - here it is again, -

(gives Friar Lawrence a letter).

Nor get a messenger to bring it thee,

So fearful were they of infection.

FRIAR LAURENCE. Unhappy fortune! by my brotherhood,

The letter was not nice but full of charge

Of dear import, and the neglecting it

May do much danger. Friar John, go hence;

Get me an iron crow, and bring it straight

Unto my cell.

FRIAR JOHN. Brother, I'll go and bring it the. (Act V, Scene 2).

In "The Comedy of Errors" "i7 the author used gender neutral pronoun they in the conversation between two female speakers Adriana and Luciana when they enter the house of Antipholus of Ephesus. The subject of female speech is about their master in a situation in which gender does not matter:

ADRIANA Neither my husband nor the slave return'd,

That in such haste I sent to seek his master!

Sure, Luciana, it is two o 'clock.

LUCIANA Perhaps some merchant hath invited him,

And from the mart he's somewhere gone to dinner.

Good sister, let us dine and never fret:

A man is master of his liberty:

Time is their master, and, when they see time,

They'll go or come: if so, be patient, sister (Act II, Scene I).

${ }^{15}$ Cusack B. Shakespeare and the Tune of the Time. Shakespeare Survey 23: Shakespeare's Language. Cambridge University Press. 1970. P. 4.

16 The Tragedy of Romeo and Juliet. URL: https://www.opensourceshakespeare.org/views/plays/play_view.php?

WorkID $=$ romeojuliet $\&$ Scope $=$ entire $\&$ pleasewait $=1 \& \mathrm{msg}=$ pl.

17 Shakespeare W. The Comedy of Errors. URL: http://www.pubwire.com/ DownloadDocs/PDFiles/SHAKESPR/COMEDY/COMEDYOF.PDF. 
Another example illustrates the usage of pronoun they as a gender neutral one in the male speech of Antipholus of Syracuse in a public place. The subject of his speech is also a situation in which gender is unknown and does not matter:

ANTIPHOLUS OF SYRACUSE

There's not a man I meet but doth salute me

As if I were their well-acquainted friend;

And every one doth call me by my name.

Some tender money to me; some invite me;

Some other give me thanks for kindnesses;

Some offer me commodities to buy:

Even now a tailor call'd me in his shop

And show'd me silks that he had bought for me,

And therewithal took measure of my body.

Sure, these are but imaginary wiles

And Lapland sorcerers inhabit here (Act IV, Scene III).

In the tragedy of "King Lear" " gender neutral pronoun is used by the male speaker Earl of Kent. The subject of his speech is a situation which is possible to happen to a man as well as to a woman:

Earl of Kent. Sir, I do know you,

And dare upon the warrant of my note

Commend a dear thing to you. There is division

(Although as yet the face of it be cover'd

With mutual cunning) 'twixt Albany and Cornwall;

Who have (as who have not, that their great stars

Thron'd and set high?) servants, who seem no less,

Which are to France the spies and speculations

Intelligent of our state (Act III, Scene 1).

The reflexive form of the pronoun they is also used with a singular antecedent every one, (spelled everyone in modern English), for example, in Shakespeare's poem The Rape of Lucrece ${ }^{19}$ :

Now leaden slumber with life's strength doth fight;

And every one to rest themselves betake,

Save thieves, and cares, and troubled minds, that wake.

18 The Tragedy of King Lear. URL: https://www.opensourceshakespeare.org/ views/plays/play_view.php?

WorkID=kinglear $\&$ Scope $=$ entire $\&$ pleasewait $=1 \& \mathrm{msg}=\mathrm{pl}$.

${ }^{19}$ Pullum G.K. Shakespeare Used 'They' With Singular Antecedents So There.

Language Log. 2006. January 05. URL:http://itre.cis.upenn.edu/ myl/ languagelog/archives/002748.html. 
As can be seen from the examples, William Shakespeare implements singular they in order to describe situations which are equally proper to men and women's lives when gender does not matter. Besides the usage of singular they is justified by lack of information on gender of a person or gender is unknown as all the roles (both male and female) in Shakespearean theatre were played by men.

William Shakespeare initiated the tendency of using gender-neutral they with pronoun everyone, which was later continued by Oscar Wilde, to describe a situation on which gender has no influence e.g.:

It is my last reception, and one wants something that will encourage conversation, particularly at the end of the season when everyone has practically said whatever they had to say, which, in most cases, was probably not much ${ }^{20}$.

Experience is the name every one gives to their mistakes ${ }^{21}$.

Oscar Wilde also used gender-neutral they with pronoun no one to describe a situation in which gender does not matter e.g.:

Oh! Go - go out of this house, All London will know why you did it; and who will blame you? No one. If they do, what matter ${ }^{22}$ ?

Thus, in classical literature of XVI - XIX centuries the authors used gender neutral singular they when gender of a person which is the subject of the conversation is unknown or to describe a situation in which gender is not important and does not matter.

\section{Gender-neutral pronouns in feminist and post-feminist literature}

Jane Austen, as one of the first truly famous female writers, is the inspiration of numerous analytical essays and literary anthologies ${ }^{23}$. Some of her most notable literary works have been a subject to intense academic scrutiny, especially at the first peak of the feminist movement and at the dawn of what came to be known as "Women's Studies" in 1960s and 1970s.

One of the aspects of her novels is a possibly unintentional, though that can be debated, avoidance of gender discrimination by her persistent choice of singular they as gender neutral pronoun instead of more

${ }^{20}$ Wilde O. The Importance of Being Earnest. URL: https://www.gutenberg.org/ files/844/844-h/844-h.htm.

21 Wilde O. Lady Windermere's Fan. URL: https://www.gutenberg.org/ files/790/790-h/790-h.htm.

22 Ibid.

${ }^{23}$ Gilbert S.M., Gubar S. The Woman Writer and the Nineteen-Century Literary Imagination. Yale University Press, 2000. 719 p. 
gender-specific ones. Further research has suggested possible reasons for usage singular they by Jane Austen. For example, in the novel "Emma" 24 the author described men and women in situations not influenced by gender: Everybody was punctual, everybody in their best looks: not a tear, and hardly a long face to be seen (p. 23). At Christmas everybody invites their friends about them, and people think little of even the worst weather (p. 102). I shall do very well again after a little while-and then, it will be a good thing over; for they say everybody is in love once in their lives, and I shall have been let off easily (p. 212). (...) and it would be quite a pity that anyone who so well knew how to teach, should not have their powers in exercise again (p. 291).

In the novel "Sense and Sensibility" 25 Jane Austen used singular they:

- to give generalizing characteristics for men and women in situations in which gender does not matter, e.g.: The sudden termination of Colonel Brandon's visit at the Park, with his steadiness in concealing its cause, filled the mind, and raised the wonder, of Mrs. Jennings for two or three days: she was a great wonderer, as everyone must be who takes a very lively interest in all the comings and goings of all their acquaintance (p. 52). Had both the children been there, the affair might have been determined too easily by measuring them at once; but as Harry only was present, it was all conjectural assertion on both sides; and everybody had a right to be equally positive in their opinion, and to repeat it over and over again as often as they liked (p. 170). Everybody has a way of their own (p. 194). Everything that the most zealous affection, the most solicitous care, could do to render her comfortable, was the office of each watchful companion, and each found their reward in her bodily ease, and her calmness of spirits (p. 248);

- to reduce empathizing the gender of a person and to show women and men's equality, e.g.: In the meantime, till all these alterations could be made from the savings of an income of five hundred a-year by a woman who never saved in her life, they were wise enough to be contented with the house as it was; and each of them was busy in arranging their particular concerns, and endeavoring, by placing around them books and other possessions, to form themselves a home (p. 22). Marianne would not let her proceed; and Elinor, satisfied that each felt their own error (p. 256).

${ }^{24}$ Austen J. Emma. Collins London and Glasgow, 1953.

${ }^{25}$ Austen J. Sense and Sensibility. Moscow, 2004. 280 c. 
In the novel "Pride and Prejudice" 26 the author used singular they:

- to give generalizing characteristics for men and women in situations in which gender does not matter, e.g.: The whole of what Elizabeth had already heard, his claims on Mr. Darcy, and all that he had suffered from him, was now openly acknowledged and publicly canvassed; and everybody was pleased to know how much they had always disliked Mr. Darcy before they had known anything of the matter (p.173). Everybody declared that he was the wickedest young man in the world; and everybody began to find out that they had always distrusted the appearance of his goodness (p. 362);

- to describe the situation when gender of the subject of the conversation is unknown, e.g.: The venison was roasted to a turn - and everybody said they never saw so fat a haunch" (p. 421).

Female characters use singular they in the conversations and dialogues mainly for description and general characteristics of both men and women in a situation when gender does not matter, e.g.:

Who makes you their confidant (Emma p. 59)?

It is very unfair to judge of any body's conduct, without an intimate knowledge of their situation (Emma p. 125).

It is very unfair to judge of any body's conduct, without an intimate knowledge of their situation (Emma p. 125) ${ }^{27}$.

But remember that the pain of parting from friends will be felt by everybody at times, whatever be their education or state (Sense and Sensibility, p. 76).

Whoever may have been so detestably your enemy let them be cheated of their malignant triumph, my dear sister, by seeing how nobly the consciousness of your own innocence and good intentions supports your spirits (Sense and Sensibility, p. 137) ${ }^{28}$.

But everybody is to judge for themselves, and the Lucases are a very good sort of girls, I assure you (Pride and Prejudice, p. 54).

You wanted me, I know, to say "Yes",' that you might have the pleasure of despising my taste; but I always delight in overthrowing those kind of schemes, and cheating a person of their premeditated contempt (Pride and Prejudice, p. 63).

26 Austen J. Pride and Prejudice. URL: http://www.planetebook.com/ebooks/ Pride-and-Prejudice.pdf (Free eBooks at Planet eBook.com).

27 Austen J. Emma. Collins London and Glasgow, 1953.

${ }^{28}$ Austen J. Sense and Sensibility. Moscow, 2004. 280 c. 
But to expose the former faults of any person without knowing what their present feelings were, seemed unjustifiable (Pride and Prejudice, p. 357) ${ }^{29}$.

Sometimes female speakers use singular they because gender of the subject of the conversation is unknown, e.g.:

Of whom does Jane ever think ill? And who is there, whatever might be their former conduct, that she would think capable of such an attempt, till it were proved against them (Pride and Prejudice, p. 348$)^{30}$ ?

Male characters use singular they to describe men as well as women in a situation when gender does not matter and to give them general characteristics, e.g.: I should be mortified indeed if I did not believe I had been of some use; but it is not everybody who will bestow praise where they may. You do not often overpower me with it (Emma, p. 59).

I wish her extremely well: and, no doubt, there are men who might not object to - Everybody has their level: but as for myself, I am not, I think, quite so much at a loss (Emma, p. 115).

Ha! This must be the very shop that everybody attends every day of their lives, as my father informs me (Emma, p. 163) ${ }^{31}$.

Perhaps, then, you would bestow it as a reward on that person who wrote the ablest defence of your favourite maxim, that no one can ever be in love more than once in their life - your opinion on that point is unchanged, I presume (Sense and Sensibility, p.68) ${ }^{32}$ ?

I cannot pretend to be sorry ... that he or that any man should not be estimated beyond their deserts; but with him I believe it does not often happen (Pride and Prejudice, p. 97).

(...) for who, as Lady Catherine herself condescendingly says, will connect themselves with such a family (Pride and Prejudice, p. 365)?

To be sure, you knew no actual good of me - but nobody thinks of that when they fall in love (Pride and Prejudice, p. 469) ${ }^{33}$.

Sometimes male speakers use singular they addressing both women and men at the same time, e.g.:

Let everybody on the Hill hear me if they can (Emma, p. 291) ${ }^{34}$.

29 Austen J. Pride and Prejudice. URL: http://www.planetebook.com/ebooks/ Pride-and-Prejudice.pdf (Free eBooks at Planet eBook.com).

30 Austen J. Pride and Prejudice. URL: http://www.planetebook.com/ebooks/ Pride-and-Prejudice.pdf (Free eBooks at Planet eBook.com).

${ }^{31}$ Austen J. Emma. Collins London and Glasgow, 1953.

${ }^{32}$ Austen J. Sense and Sensibility. Moscow, 2004. 280 c.

33 Austen J. Pride and Prejudice. URL: http://www.planetebook.com/ebooks/ Pride-and-Prejudice.pdf (Free eBooks at Planet eBook.com).

${ }^{34}$ Austen J. Emma. Collins London and Glasgow, 1953. 
Thus, in the novels by Jane Austen the female characters and the author herself often use gender neutral pronoun they in the situation when gender is unknown, when they want to reduce the emphasis on gender in order to show equal social status of women and men. Male characters in her novels use singular they in the situations when gender does not matter or addressing the people of both sexes.

While the first cases of using gender neutral pronouns should be regarded as unconscious ones, modern literature demonstrates conscious usage of gender neutral pronouns and even reflects the appropriateness of such language units in connection with political correctness.

In the novel "Talking it over" by Julian Barnes ${ }^{35}$ the arguments for and against using singular they are discussed and analyzed via dialogue between characters with opposite opinions. The author underlines the conscious choice of using singular they for description of the situation which is not influenced by gender e.g.: Everyone else around here has changed their name (...). Now, did you noticed how I said everyone followed by their (p. 5)?

During the discussion the characters express different attitudes towards using gender-neutral language units in order to avoid gender asymmetry e.g.:

Oliver said that words like everyone and someone and no one are singular pronouns and must therefore be followed by the singular possessive pronoun, namely his. Gillian said you couldn't make a general remark and then exclude half the human race, because fifty per cent of the time that someone will turn out to be female. So for reasons of logic and fairness you ought to say his or her (...).

Stuart then came up with a solution. His being either inaccurate or insulting or quite possibly both, and his or her being diplomatic but awfully cumbersome, the obvious answer was to say their (p. 7-8).

Stuart supported using singular they while Oliver and Gillian were against.

His opponents accepted singular they only in a situation when gender of the subject of the conversation is unknown e.g.:

Someone just put their head round the door (p. 16).

Thus, the conducted research proved that contemporary authors consciously use gender neutral pronouns and analyze the reasons for their usage.

35 Barnes J. Talking It Over. URL: https://www.overdrive.com/media/559829/ talking-it-over. 


\section{Gender neutral pronouns in modern English language media}

Starting from the middle of the XX century the necessity to create equal conditions and rights for all regardless gender has become appealing to many people. One of the aims of this movement was to find a politically correct way of addressing people without any chance for discrimination.

Modern ways of using gender neutral pronouns have been studied by collecting and analyzing data from modern sources of information including Internet articles and YouTube materials. The analysis has shown that gender neutral pronouns (also called non-binary) are used by individuals that do not refer themselves to traditional categories of gender and are members of LGBTQ + community, they are also utilized to emphasize the equality of genders and as the act of political correctness.

As a result of this shift, nowadays more and more businesses, NGOs, and individuals who identify themselves all the way across the gender spectrum, start accepting what non-binary people have been arguing for quite a while: traditional pronouns he and she don't include everybody, with gender identity being a spectrum with many in-between positions, rather than a he or she toggle. This comes around the rise in popularity of a habit to list pronouns a person prefers to be addressed by in their social media bios and email signatures, serving as a kind reminder that gender identity is a complicated matter that cannot and should not be judged solely by one's biological sex.

Plainly speaking, the use of singular they is on the rise. Whereas traditionally writers have been using it in two main ways: "when referring to a generic person whose gender is unknown or irrelevant to the context" and "when referring to a specific, known person who uses 'they' as their pronoun",36, nowadays bloggers and speakers, podcast hosts and news anchors, as well as regular people are all starting to take up they as a way to refer to an individual whose gender identity is nonbinary. This take up has secured it a prominent spot in the language of modern media outlets, and was further recognized by such a titan of the English language as Merriam-Webster dictionary. The logic behind awarding it such an honorable prize as the Word of the Year award,

\footnotetext{
${ }^{36}$ North A. The Past, Present and Future of the Singular "They". The pronoun is Merriam-Webster's Word of the Year. Here's why. Vox. 2019. Dec 13. URL: https://www.vox.com/2019/12/13/21011537/they-merriam-webster-pronounsnonbinary-word-year.
} 
according to the publisher, is "that the pronoun - which for hundreds of years was used as a gender-neutral singular pronoun - no longer fills just that role, and has been increasingly used to refer to a person whose gender identity is non-binary" ${ }^{37}$.

Non-binary they was also prominent in the news in 2019 and the American Psychological Association's blog officially recommended that "singular they be preferred in professional writing over "he or she" when the reference is to a person whose gender is unknown or to a person who prefers they" 38 .

Singular they doesn't depend on personal dialect and is spreading very fast. Facebook is using singular they when referring to a person whose gender is unknown: "I signed up in Facebook before they started asking for gender. I've never actually told them that I'm a guy. So my friends see "Tom Scott updated their profile picture"39.

Non-binary pronouns are used in modern media outlets mainly for the following reasons:

- to address non-traditional groups of people, e.g.: "I'm okay with that. Because some people are "they", Get over it",40.

- to emphasize gender variability, e.g.: "Recently I've come across "they" and I like "they", so you can refer to me as either as she or they",

- to refer to transgender (non-binary) people, e.g.: "I've found out about gender non-specific pronouns ze and hir and I thought that was funny? That's make people trip up, cause really, technically, I'm not a "she". I'm not a "he" either",

- to be respectful to the choice of non-binary people concerning gender, e.g.: "So some people go by "he", some people go be "she", some people actually use the pronoun "they",43.

37 Schreiner M. How 'They' Became The Word Of The Year. URL: https://wusfnews.wusf.usf.edu/post/how-they-became-word-year.

38 Word of the Year 2019 "They"/ Merriam-Webster. URL: https://www.merriam-webster.com/words-at-play/word-of-the-year.

39 Gender Neutral Pronouns: They're Here, Get Used To Them. URL: https://youtu.be/46ehrFk-gLk.

${ }^{40}$ Ibid.

41 Why Matter For Prans People.

URL: https://youtu.be/N_yBGQqg7kM.

${ }^{42}$ Ibid.

43 Ibid. 
- to avoid misgendering a person by using incorrect pronoun while addressing LGBTG + community people, e.g.: "You can avoid mistakes by just saying them/theirs/they",44.

- to emphasize LGBTG + community affiliation, e.g.: (...) the use of "they" as a singular noun in place of "he" or "she" for people who are transgender or who identify variously as agender, androgyne, pangender, gender-fluid, gender-queer ${ }^{45}$.

- to avoid identifying gender identity, e.g.: "Similarly, there are some people who identify as male. There are some people who identify as female. And there are some people who don't want to identify and want to still be able to be spoken about in a sentence. And they and them is perfect for that. It sounds plural to people immediately, but I think as this country begins to get used to the sound of they and them - which I have, you know, it took me a while - it took me probably a year to have they or them role off the tongue. But it's just the way to speak about somebody where you don't want to gender them ",46.

- to reveal the fact, that the person is non-binary, e.g.: (...)the dad we've always known on "Arrested Development" is revealing themselves. You know, that familiarity with audiences as a man and, oh, we love them anyway. We still love them as a woman. We love them more as a woman $^{47}$.

The usage of gender neutral pronouns is also common in modern TV shows (Shameless ${ }^{48}$, Billions ${ }^{49}$, The Bridge $e^{50}$ ), which often portray young people that do not fit into traditional social groups:

- identifying non-binary gender identity:

"I identify as non-binary, which means I'm neither male, nor female and in a correspondence I use "They/Them pronouns".

${ }^{44}$ Ibid.

45 Why "They" Was Voted the Word of the Year. Comma Queen. URL: https://youtu.be/CJrIcrHrfM4.

${ }^{46}$ Soloway J. Funny, Dirty, Sad: The 'Holy Trinity' For 'Transparent'. National Public Radio. 2014. October 30. URL: http://www.npr.org/templates/ transcript/transcript.php?storyId=360116374.

${ }^{47}$ Soloway J. Funny, Dirty, Sad: The 'Holy Trinity' For 'Transparent'. National Public Radio. 2014. October 30. URL: http://www.npr.org/templates/ transcript/transcript.php?storyId=360116374.

${ }^{48}$ Shameless, 2011-2017. URL: https://youtu.be/ssTZtRQmhxY.

49 Billions. Season 2. Series 3, 2017. URL: https://itunes.apple.com/us/tvseason/optimal-play/id1239530964.

${ }^{50}$ The Bridge. Series 3. Episode 1, 2015. BBC. URL: https://www.bbc.co.uk/ programmes/b06dl825. 
"Gender-fluid heteroromantic demisexual (...). My pronoun is "zie".

"Genderqueer (...). "Ve, vem, vir".

"Agender intersex AFAB (assigned female at birth). My pronoun is "they,"s1.

"Hello, I'm Taylor. My pronouns are 'they', 'theirs' and 'them ",52.

- emphasizing LGBTG + community affiliation:

"When we talk about demisexual, we say:" Ask them if they would like a coffee ${ }^{, 53}$.

- referring to a generic person whose gender is unknown or irrelevant to the context:

- So, hen knows the area?

- Sorry... "hen"? What does that mean?

- It's a gender-neutral personal pronoun.

- What's wrong with "he" and "she"?

- "Hen" is practical when the sex of the person is unknown. Politically correct, at least ${ }^{54}$.

With the advent of a transgender alternative, students and professors of Wesleyan University have turned to use a gender-neutral alternative Ze/Zir/Zirs, in order to be respectful to the rights of all the students' gender identity: "Some Wesleyan professors are comfortable with the term; others are not. In my experience, when we introduce ourselves for various groups like sports teams or classes, naming your pronoun is as common as naming your class year. I hear and use ' $z e$ ' and its possessive companion 'hir' multiple times a day." Learning the dynamics of " $z \boldsymbol{e}$ " is also a part of First-Year Orientation. Wesleyan student says " $z e$ " isn't exactly ubiquitous there either. "It is more frequently invoked with irony, 55 .

Numerous examples can be found on the University website:

"I have recently noticed the high frequency at which we casually ask the question "Is ze smart?"

Instead, this answer seems to require some sort of explanation: " $Z \boldsymbol{e}$ is good at art," "Ze writes really well," or "Ze is an amazing dancer".

${ }^{51}$ Shameless, 2011-2017. URL: https://youtu.be/ssTZtRQmhxY.

52 Billions. Season 2. Series 3, 2017. URL: https://itunes.apple.com/us/tvseason/optimal-play/id1239530964.

${ }_{54}^{53}$ Shameless, 2011-2017. URL: https://youtu.be/ssTZtRQmhxY.

${ }_{54}$ The Bridge. Series 3. Episode 1, 2015. BBC. URL: https://www.bbc.co.uk/programmes/b06dl825.

55 Caputo B.B. Gender Neutrality Hits Wesleyan. Nov 2, 2005. URL: http://www.thecrimson.com/article/2005/11/2/gender-neutrality-hits-wesleyan-with-the. 
What makes someone who excels in calculus require only a simple "yes" while someone who is an extraordinary artist necessitates an explanatory "Ze's a good painter?",56.

\section{CONCLUSIONS}

The results of the research have proved that gender neutral pronouns play an important role in the English speaking world. The first unconscious introduction of gender neutral pronouns in the English literature was made by such well-known authors as William Shakespeare, Oscar Wilde, Jane Austen using singular they in cases when the information about person's gender is not available or unknown, in the situations when gender does not matter or addressing the people of both sexes in order to show the equality of the social status of men and women.

While the first cases of using gender neutral pronouns should be regarded as unconscious ones, modern literature demonstrates conscious usage of gender neutral pronouns and even reflects the appropriateness of such language units in connection with political correctness.

With feminist and LGBTG + community movement becoming stronger, gender neutral singular they became wide-spread and new gender neutral pronouns appeared. As the members of social minority groups begin to fight for their rights, the replacement of gender-marked by gender neutral units becomes more and more obvious in modern literature and mass media.

According to the results of our research gender neutral pronouns are used in modern media outlets when there is no information about gender identity, gender is unknown, concealed or intentionally revealed, in order to avoid gender discrimination and to be respectful of people who don't identify as he or as she. Thus, the gender neutral singular pronoun they, which was traditionally used to address to a person with unknown gender, nowadays is increasingly used to refer to a person whose gender identity is non-binary. New gender neutral pronouns let speakers avoid gender discrimination as an act of political correctness and to gain the insight into alternative cultures which will make us more respectful and tolerant to other people's gender identity.

The Wesleyan Argus. URL: http://www.thecrimson.com/article/ 2005/11/2/gender-neutrality-hits-wesleyan-with-the. 


\section{SUMMARY}

The research reveals the peculiarities of formation and functioning of gender neutral pronouns in the English literature from Shakespearean to modern times under the influence of social and historical factors. The gender neutral pronouns are characterized and analyzed according to the purposes and areas of their application. The research is focused on the functional changes of the traditional gender neutral pronouns in the English literature and principles of characterizing new non-traditional gender neutral pronouns according to their usage in modern media. The study has proved that gender neutral pronouns are used when there is no information about gender identity, in order to avoid gender asymmetry and gender discrimination as an act of political correctness. While the first introduction of gender neutral pronouns was made equalizing the social status of men and women, nowadays the traditional and new gender neutral pronouns are used referring to a person with unknown gender or to an individual whose gender identity is non-binary and let the speakers avoid gender discrimination.

\section{References}

1. Austen J. Sense and Sensibility. Moscow, 2004. 280 c.

2. Austen J. Emma. Collins London and Glasgow, 1953.

3. Austen J. Pride and Prejudice. URL: http://www.planetebook.com/ebooks/Pride-and-Prejudice.pdf (Free eBooks at Planet eBook.com).

4. Barnes J. Talking It Over. URL: https://www.overdrive.com/ media/559829/talking-it-over.

5. Billions. Season 2. Series 3, $2017 . \quad$ URL: https://itunes.apple.com/us/tv-season/optimal-play/id1239530964.

6. Brown M., Moorer R. Applied Research on Gender and Women's Studies. International Encyclopedia of the Social \& Behavioral Sciences (Second Edition). 2015. URL: https://www.sciencedirect.com/ topics/social-sciences/womens-studies.

7. Butler J. Gender Touble: Feminism and the Subversion of Identity. New York : Routledge, 1990.

8. Caputo B.b. Gender Neutrality Hits Wesleyan. Nov 2, 2005. URL: http://www.thecrimson.com/article/2005/11/2/gender-neutrality-hitswesleyan-with-the.

9. Cusack B. Shakespeare and the Tune of the Time. Shakespeare Survey 23: Shakespeare's Language. Cambridge University Press, 1970. P. 1-12. 
10.Ehrlich S. Language and Gender. The Handbook of Applied Linguistics. Blackwell Publishing Ltd. 2004. P. 304-328.

11. Evans B.I. The Language Of Shakespeare's Plays. London, 3rd ed. 1964.

12. Frank F., Anshen F. Language and the Sexes. State University of New York Press, 1991. 217 p.

13. Gender Neutral Pronouns: They're Here, Get Used To Them. URL: https://youtu.be/46ehrFk-gLk.

14.Gilbert S.M., Gubar S. The Woman Writer and the NineteenCentury Literary Imagination. Yale University Press, 2000. 719 p.

15. Gordon G. Shakespeare's English. Shakespearian Comedy. Oxford, reprint, 1945.

16. Hudson K. Shakespeare's Use of Colloquial Language. Shakespeare Survey 23: Shakespeare's Language. Cambridge University Press, 1970. P. 39-48.

17. Maltz D., Borker R. A Cultural Approach to Male-Female Miscommunication. Language and Social identity. Cambridge : Cambridge University Press, 1982. P. 196-216.

18. North A. The Past, Present and Future of the Singular "They". The pronoun is Merriam-Webster's Word of the Year. Here's why. Vox. 2019. Dec 13. URL: https://www.vox.com/2019/12/13/21011537/theymerriam-webster-pronouns-nonbinary-word-year.

19. Pullum G. K. Shakespeare Used 'They' With Singular Antecedents So There. Language Log. 2006. January 05. URL:http://itre.cis.upenn.edu/ myl/ languagelog/archives/002748.html.

20.Salmon V. Some Functions of Shakespearian Word-formation. Shakespeare Survey 23: Shakespeare's Language. Cambridge University Press, 1970. P. 13-26.

21. Shakespeare W. The Comedy of Errors. URL: http://www.pubwire.com/ DownloadDocs/PDFiles/SHAKESPR/COMEDY/COMEDYOF.PDF.

22. Shakespeare W. The Tragedy of King Lear. URL: https://www.opensourceshakespeare.org/views/plays/play_view.php?Wo rkID $=$ kinglear $\&$ Scope $=$ entire $\&$ pleasewait $=1 \& \mathrm{msg}=\mathrm{pl}$.

23. Shakespeare W. The Tragedy of Romeo and Juliet. URL: https://www.opensourceshakespeare.org/views/plays/play_view.php?Wo rkID $=$ romeojuliet $\&$ Scope $=$ entire $\&$ pleasewait $=1 \& \mathrm{msg}=\mathrm{pl}$.

24. Shakespeare W. The Rape of Lucrece. URL: http://shakespeare.mit.edu/ Poetry/RapeOfLucrece.html.

25. Shameless, 2011-2017. URL: https://youtu.be/ssTZtRQmhxY. 
26. Schreiner M. How 'They' Became The Word Of The Year. URL: https://wusfnews.wusf.usf.edu/post/how-they-became-word-year.

27. Smithers G.V. Guide-Lines for Interpreting the Uses of the Suffix -ed in Shakespeare's English. Shakespeare Survey 23: Shakespeare's Language. Cambridge University Press, 1970. P. 27-37.

28. Soloway J. Funny, Dirty, Sad: The 'Holy Trinity' For 'Transparent'. National Public Radio. 2014. October 30. URL: http://www.npr.org/templates/transcript/transcript.php?storyId= 360116374.

29. Stoller R.J. Sex and Gender: On the Development of Masculinity and Femininity. New York : Science House, 1968.

30.The American Heritage. Book of English Usage. A Practical and Authoritative Guide to Contemporary English. Boston : Houghton Mifflin, 1996. URL: http://web.archive.org/web/20080415023135/ http://www.bartleby.com:80/64/C005/012.html\#HE.

31. The Bridge. Series 3. Episode 1, 2015. BBC. URL:https://www.bbc.co.uk/programmes/b06dl825.

32.The Wesleyan Argus. URL: http://www.thecrimson.com/ article/2005/11/2/ gender-neutrality-hits-wesleyan-with-the.

33. West C., Zimmerman, D. Doing Gender. Gender and Discourse. London : Sage, 1987. P. 1-20.

34. Wilde O. Lady Windermere's Fan. URL: https://www.gutenberg.org/files/790/790-h/790-h.htm.

35. Wilde $\mathrm{O}$. The Importance of Being Earnest. URL: https://www.gutenberg.org/files/844/844 -h/844-h.htm.

36. Why Pronouns Matter For Trans People. URL: https://youtu.be/N_yBGQqg7kM.

37. Why "They" Was Voted the Word of the Year. Comma Queen. URL: https://youtu.be/CJrIcrHrfM4.

38. Word of the Year 2019 /"They"/ Merriam-Webster. URL: https://www.merriam-webster.com/words-at-play/word-of-the-year.

\section{Information about the author: Klymenko Olga Leonidivna,} Candidate of Philological Sciences, Full Professor, Professor at the English Translation Department Zaporizhzhia National University 66, Zukovsky str., Zaporizhzhia, 69600, Ukraine 